\title{
As brigadas muralistas da experiência chilena: propaganda política e imaginário revolucionário
}

Carine Dalmás*

\begin{abstract}
Resumo:
O presente artigo tem como propósito analisar duas organizações de propaganda e alguns dos murais produzidos por elas no Chile durante governo da Unidade Popular (UP). Neste período a esquerda chilena tentou desenvolver o projeto de transição para o socialismo pela via pacífica. As imagens foram produzidas com fins propagandistas por brigadas muralistas que pertenciam aos principais partidos do governo - o Partido Comunista (PC) e o Partido Socialista (PS). A maneira como se estruturaram e as mensagens pictórico-textuais produzidas por estas organizações nos permitiram observar algumas facetas da atuação dos principais partidos do governo na luta políticocultural que encabeçaram em torno deste projeto comum. Partimos da hipótese de que as imagens produzidas traduzem, enquanto documentos históricos, os valores políticos e ideológicos da UP e, também, as suas tensões políticas internas. As brigadas muralistas tinham o objetivo de conscientizar e conquistar o apoio da sociedade para a transformação do Chile em um país socialista e, sendo assim, contribuíram para a construção de um imaginário socialista.O estudo da forma pela qual a propaganda visual da UP difundiu este imaginário constitui o eixo central desta abordagem que se circunscreve, do ponto de vista historiográfico, no campo da história das representações. Entendemos que a análise das imagens expressas nos murais nos permite apreender o significado do imaginário que orientou as práticas políticas do PC e do PS chilenos naquele período.
\end{abstract}

Palavras-chave: Brigadas Muralistas, Experiência Chilena, Imaginários Sociais.

As brigadas muralistas foram organizações juvenis criadas no final da década de sessenta para fazer propaganda política dos projetos e dos candidatos dos principais partidos de esquerda chilenos - o Partido Comunista (PC) e o Partido Socialista (PS). Suas mensagens mesclavam elementos pictóricos e textuais e eram realizadas em muros e paredes das ruas do país. As precursoras foram a Brigada Ramona Parra (BRP), criada pelas Juventudes Comunistas do Chile (JJCC), e a Brigada Elmo Catalán (BEC), pertencente à Federação da Juventude Socialista (FJS).

O auge dos trabalhos dessas organizações ocorreu entre 1970 e 1973, período em que o Chile viveu uma tentativa de transição para o socialismo pela via pacífica, ou seja, sem romper com a institucionalidade vigente e primando pela manutenção da democracia. Nesse período, comumente chamado de experiência chilena, a coligação de 
esquerda Unidade Popular (UP), ${ }^{1}$ liderada pelo presidente Salvador Allende, chegou ao governo eleita democraticamente em 4 de setembro de 1970 e constituiu-se como uma outra possibilidade de revolução socialista na América Latina. Essa experiência foi interrompida no dia 11 de setembro de 1973, por meio de um violento golpe militar promovido por forças chilenas e estrangeiras.

$\mathrm{Na}$ pesquisa de mestrado realizamos uma análise da experiência chilena tomando como documento as imagens de propaganda política produzidas pela BRP e pela BEC e, ainda, alguns cartazes elaborados no Escritório dos Irmãos Larrea. Consideramos que essas imagens serviram como instrumento para nossa pesquisa porque, no âmbito de sua produção e ação, interagiram com a sociedade ao produzir sentidos na busca de mobilização de valores determinados. ${ }^{2}$ A trama discursiva, tanto das mensagens pictórico-textuais, como da ação das brigadas no espaço público, articularam representações coletivas e as relacionaram com a construção de um novo imaginário social para o Chile: o imaginário socialista. Neste breve artigo procuramos mostrar como as BEC e as BRP contribuíram para a construção desse imaginário através de suas ações político-culturais e, ainda, como revelaram contradições que marcaram o governo da UP.

\section{A Origem}

A criação das brigadas muralistas localiza-se em dois momentos da trajetória eleitoral do PC e do PS no Chile: as campanhas pela eleição de Salvador Allende em 1964 e 1970.

Depois da reformulação da legislação eleitoral, ${ }^{3}$ em meados dos anos 1950, o Partido Democrata Cristão (PDC) se tornou o maior partido político do país e a Frente Revolucionária de Ação Popular (Frap), ${ }^{4}$ uma reunião de partidos de tendência marxista. Estes, entusiasmados com os resultados eleitorais alcançados na disputa de 1958, iniciaram uma campanha marcada pelo otimismo e por uma disposição militante, que motivou as primeiras criações de murais realizadas coletivamente. ${ }^{5}$

O relato mais referendado sobre os primórdios do muralismo brigadista foi o de Patricio Cleary (1988), militante de esquerda encarregado da propaganda do candidato Salvador Allende em 1963-1964, publicado na revista Araucaria de Chile. ${ }^{6}$ Segundo o autor, a iniciativa de elaborar a propaganda da Frap nas paredes e nos muros das cidades chilenas surgiu em Valparaíso (principal cidade portuária do país) e visava superar a 
falta de recursos econômicos para se contrapor à grande estrutura propagandista do seu rival, o candidato democrata cristão Eduardo Frei Montalva (Cleary, 1988, p.93). ${ }^{7}$ Nos primeiros dias da campanha, aberta em maio de 1963, muitas ruas em diferentes cidades do país amanheceram com muros pintados com as "estrelas de Frei", símbolo da sua candidatura.

Como resposta, a Frap organizou uma ampla mobilização de seus comitês de jovens militantes e, no mesmo mês, na cidade de Valparaíso, responderam com o que Patricio Cleary denominou ofensiva callejera (ofensiva de rua), enchendo muros e paredes com o "X" da campanha de Salvador Allende.

$\mathrm{O}$ símbolo composto pela letra "V" de vitória na parte superior, pelo "A" de Allende na inferior e pelas cores da bandeira nacional chilena foi pintado por todo o país e deu ensejo para o desencadeamento de uma série de iniciativas similares. Apesar dos problemas de organização, a realização da propaganda política através de mensagens textuais e pictóricas foi eficaz para a motivação e o envolvimento dos militantes ao ponto de despertar o interesse de artistas que se dispuseram a contribuir para ampliar e especializar essa prática propagandista. Sobre esse fato relatou Patrício Cleary:

\footnotetext{
Foi neste clima que surgiu, produto de conversas entre o pintor Jorge Osorio, um estudante de arquitetura com muitas habilidades artísticas chamado Osvaldo Stranger e o autor desta crônica que era encarregado da propaganda da campanha -, a idéia de experimentar fórmulas propagandistas diferentes, como representar, por exemplo, artisticamente, em cartazes pintados diretamente nos muros, as consignas e aspirações populares. Aprovamos a idéia a partir de um esboço que, sem propósito concreto, havia desenhado Osorio em seus poucos momentos de ócio. Foi mais fácil despertar o entusiasmo de todos nós do que encontrar, em seguida, os meios para sua realização. ${ }^{8}$ Finalmente, o problema se resolveu e escolhemos um muro localizado na avenida Espanha, a estratégica artéria que une Valparaíso com Viña del Mar [outra importante cidade do litoral chileno]. Osorio e Stranger, apoiados por um comitê de jovens, pintaram o mural em uma noite.

Foi esse o primeiro mural político, até onde sabemos, pintado no país. Era o mês de julho de 1963. (Ibid., p. 194).
}

A realização deste mural estimulou a pintura de outros, ao longo da Avenida Espanha, por comitês juvenis que se encarregaram de cobrir toda sua extensão com o "X" da campanha de Allende. Alguns murais se destacaram pela elaboração estética e pela mobilização de militantes, estudantes universitários e da população em geral que acompanhavam a sua produção. Ao descrever o mural pintado na ponte Capuchinos, também no caminho entre Valparaíso e Viña del Mar, Patrício Cleary lembrou que durante o processo de sua produção, o mural se converteu em objeto de romaria popular 
e de atividades dos comitês da campanha eleitoral que acompanhavam a evolução dos trabalhos e levavam alimentos e refrescos para os pintores (ibidem). As iniciativas de Valparaíso inspiraram uma onda de realizações similares por todo o país, porém destas ou de outras não tivemos acesso a imagens.

Patrício Cleary ressaltou ainda o estabelecimento de debates através dos muros, pois a muitos dos murais produzidos pelos militantes da Frap os democrata-cristãos responderam com outros murais e vice-versa. Essa dinâmica persistiu, sobretudo na cidade de Valparaíso, até o resultado final das eleições com a vitória de Eduardo Frei.

A produção de murais nas ruas do Chile por militantes de esquerda só foi retomada novamente de maneira esparsa no final dos anos 1960, quando se aproximavam novas eleições presidenciais. O relato de Eduardo Carrasco (militante comunista que participou do movimento da Nova Canção Chilena e das BRP) descreveu o início do segundo momento dessa prática muralista. Segundo o autor, foram realizações voltadas para a denúncia dos desmandos políticos do governo do presidente Eduardo Frei Montalva, como, por exemplo, o massacre de Puerto Montt. ${ }^{9}$ Denunciavam também as atrocidades realizadas pelos EUA no Vietnã, seguindo uma linha antiimperialista. Os agentes dessas iniciativas eram adolescentes que tinham em média 16 anos e, muitos deles, eram membros do PC.

Um exemplo dessas iniciativas isoladas, sobre as quais também não possuímos registros visuais, foi a "Marcha dos Três A" (Anticapitalista, Antioligárquica e Antifeudal). Ocorreu em setembro de 1969, saiu de Valparaíso em direção a Santiago e, de acordo com Eduardo Carrasco, foi o impulso para a formação das brigadas muralistas do PC, as BRP, que atuariam na campanha de eleitoral de 1970. Conforme relatou o autor,

\footnotetext{
com um velho jeep americano da Segunda Guerra Mundial, fizemos - cinco ou seis rapazes todo o percurso da marcha, pintando grandes pedras que se encontram ao lado da estrada que nos leva a Santiago. Tivemos a aceitação da população e, nas cidades em que este grande cortejo alegre e multicolorido parava, realizávamos com o povo escritas alusivas à paz e contra a guerra. (Carrasco, 2004, p.19)
}

Segundo Patrício Cleary, observando a eficácia mobilizadora e comunicativa da elaboração de murais de forma coletiva, Salvador Allende teria sido um dos incentivadores da retomada dessa prática muralista na campanha eleitoral da UP em 1970 (Cleary, 1988, p.195). De fato, tal experiência foi retomada e estruturada pelos militantes da UP e deram origem às brigadas muralistas. 


\section{O Sentido do Nome}

A compreensão da denominação brigada muralista, em uma perspectiva histórica, permite apreender o sentido e a natureza desse fenômeno político-cultural. A idéia de brigada remete à maneira de organização de trabalhos coletivos que se originou na URSS nos primeiros anos posteriores à Revolução de 1917, quando se formaram “'brigadas de escritores', 'brigadas de músicos' etc., e Trotski chegou a propor as 'brigadas de trabalho' e a militarização de todos os operários" (Schnaiderman, 1997, p.37). Esse modelo de ação também foi adotado em Cuba, após a revolução de 1959, onde o trabalho coletivo foi considerado elemento do qual dependia a superação do subdesenvolvimento do país e o sucesso da revolução.

O valor do trabalhador e/ou do trabalho e da atuação coletiva esteve no cerne da estruturação da ação das brigadas. Segundo Alejandro González, ${ }^{10}$ pintor muralista e diretor artístico das BRP entre 1970 e 1973, a elaboração coletiva dos murais implicou uma criação submetida a uma organização das atividades em etapas bem definidas e realizadas por grupos de no máximo doze pessoas, nas quais cada um deveria exercer uma função específica. Enquanto um brigadista ficava de guarda, um líder, em geral quem desenhava melhor, escrevia o slogan na parede escolhida e cada membro da equipe tinha de pintar uma área específica. As tarefas eram divididas de acordo com as possibilidades e capacidades de cada participante, criando-se, inclusive, novos termos técnicos para denominá-las: havia os "pintores do fundo", que com tinta branca "limpavam" o muro, os "traçadores" para desenhar, os "enchedores" para pintar as figuras, e, por último, os responsáveis por fazer o contorno preto. Esse contorno foi uma marca importante do muralismo das BRP e tinha como função reparar defeitos da pintura e realçar as cores (González, 2004). Inicialmente, os trabalhos eram realizados à noite, de forma clandestina para que a polícia ou militantes dos partidos opositores não impedissem a produção ou destruíssem os murais antes do amanhecer. Depois da vitória da UP, com o fim da repressão policial, as brigadas passaram a atuar também durante o dia.

Algumas imagens fotográficas registraram o processo de mobilização e produção muralista das BRP no ano de 1972. Os brigadistas, vestindo macacões doados por sindicatos e capacetes com a sigla de sua brigada e carregando seus materiais de trabalho, bandeira e cartazes com o nome das brigadas, chegavam em um velho 
caminhão ao local eleito para realizar o mural e, assim, demarcavam a identificação dos jovens militantes de esquerda com os trabalhadores. A ação propagandista se tornou assim, uma maneira de recuperar o valor do trabalho e da ação coletiva que estava no cerne do projeto de transição para o socialismo.

A escolha do muralismo também agregou valores nesse mesmo sentido, ao se inspirar no movimento muralista mexicano. ${ }^{11}$ A aproximação com o movimento muralista mexicano se deu pela proposta de realização coletiva das pinturas com base nos postulados de socialização da arte. Isso representava uma contraposição ao individualismo burguês e, com ele, à pintura de cavalete e qualquer proposta artística voltada para os meios intelectuais elitistas. Segundo o antropólogo argentino Nestor Garcia Canclini (1980), a partir da idéia de uma arte socializada, estabelecia-se a crítica da função da arte em uma estrutura social capitalista e a defesa da articulação entre o lúdico e o político (Canclini, 1980, p.130, 153).

A busca da revelação de uma identidade nacional também foi um fator de aproximação com os mexicanos. Porém, enquanto os muralistas mexicanos pretenderam representar uma identidade mexicana, buscada nas origens históricas do México, incluindo vários aspectos da cultura pré-colombiana, as brigadas muralistas chilenas preocuparam-se em consolidar uma identidade nacional revolucionária centrada na figura do trabalhador chileno, colocando-o como agente fundamental daquele processo.

No entanto, o muralismo mexicano, assumindo aqui as constatações do crítico Octavio Paz, partiu das especulações de um grupo de artistas e intelectuais formados e consagrados nas instituições de arte burguesas, constituindo assim um movimento de vanguarda artística, um processo de ruptura financiado pelo Estado e nascido dentro das instituições tradicionais de artes plásticas (Paz, 1987).

Já o muralismo das brigadas chilenas, em perspectiva oposta, assumiu um caráter efêmero, centrado em objetivos propagandistas imediatos e, portanto, condicionando a criação artística ao objetivo de integração dos trabalhadores na luta política do governo. A realização dos murais seguia a contingência política do momento, portanto eram elaborados em locais estratégicos (bairros de periferias, próximos ou nas indústrias e mineradoras, em muros e calçadões de boa visibilidade aos transeuntes) e substituídos assim que o objetivo da mensagem era superado. ${ }^{12}$ Seus produtores eram militantes de esquerda apoiados por alguns artistas, também militantes, e financiados com os recursos financeiros provenientes do partido ou de doações. O valor desse muralismo estava diretamente relacionado à correspondência de suas 
mensagens às preocupações político-culturais dos seus partidos de origem e/ou da UP. Em termos de experimentação artística, gerou um método alternativo de pintura mural baseado, essencialmente, na utilização de materiais simples, na rapidez, na simplicidade estética e no trabalho em equipe de jovens voluntários.

As brigadas muralistas, mesmo quando reconhecidas nas instituições de arte tradicionais, mantiveram tais princípios de trabalho e, sendo assim, consolidaram-se como uma outra tendência do muralismo chileno. ${ }^{13}$ A conceituação dessa nova tendência pode ser sintetizada a partir das duas funções atribuídas às brigadas muralistas pelo crítico Carlos Leon. A primeira, de informação e convicção ideológica, ligou-se à sua proposta de massificação da informação, para se estabelecer como contraponto aos meios de comunicação tradicionais e hegemônicos. A segunda função, de criação e participação, relacionou-se à representação da prática brigadista no espaço público que integrava militantes, artistas e transeuntes no seu processo criativo (Leon, 1983, p.116).

Tais aspectos marcaram a novidade e a eficácia simbólica deste movimento por representarem os valores político-culturais que fundamentavam o projeto de construção de uma sociedade socialista no Chile. No entanto, o trabalho das brigadas precursoras BRP e BEC -, desde a escolha de seus nomes, estabeleceu representações que trouxeram à tona também as diferenças entre seus partidos de origem.

\section{As Brigadas Ramona Parra}

A BRP foi a primeira organização de propagandistas a se organizar no Chile em brigadas. Nasceu da reunião de militantes comunistas que participaram da campanha de 1963-1964, que atuaram nas ações de protesto do final de 1960 e, ainda, por integrantes da Brigada Venceremos, também criada pelas JJCC na eleição de 1970.

O nome desta brigada, assim como da revista das JJCC, a revista Ramona, ${ }^{14}$ foi uma homenagem a Ramona Parra, a primeira "mártir" das JJCC. Ela morreu aos 19 anos no dia 29 de janeiro de 1946, em um confronto com policiais na Praça Bulnes (localizada em frente ao palácio do governo na capital Santiago), durante uma manifestação da Confederação de Trabalhadores do Chile (CTCH).

Uma entrevista exclusiva cedida à revista Ramona pela irmã de Ramona Parra, Olga Parra Alarcón, permitiu-nos observar como a valorização da trajetória dessa militante, procurou legitimar um modelo de jovem revolucionário e de militância 
feminina. Os aspectos ressaltados pela entrevista combinaram uma conduta familiar exemplar - apego aos pais, irmãos e sobrinhos - com a preocupação pelas causas sociais e o conseqüente ativismo político ligado às JJCC.

Segundo a entrevista, Ramona Parra ou a "heroína" (termo recorrente no texto) optou por fazer concessões incomuns para uma jovem mulher, como casar-se e ter filhos, porque desejava integrar-se totalmente à luta política. Nessa perspectiva, na qualidade de estudante e trabalhadora, valorizava o contato com os trabalhadores e isso a teria motivado a filiar-se nas JJCC. Na ação política de Ramona Parra ganhou destaque sua impetuosidade na manifestação em que foi assassinada. Características de personalidade que, através da transcrição da fala de Olga Parra Alarcón, foram relacionadas às ações das BRP:

Ramona era uma moça doce, agradável, boa amiga, boa companheira. Eu a vi desde criança, desde muito jovem, inquieta e audaz no cumprimento das tarefas. Assim como se vê agora os jovens, as moças que saem nas noites dedicadas à propaganda política. (Lanzarotti, 1972, p.21)

A entrevista estabeleceu, assim, representações que fundamentavam o papel revolucionário da juventude e a valorização da integração da mulher na luta. Proposições que estavam em conformidade com algumas das resoluções do XIV Congresso Nacional do PC, realizado em 1969.

Segundo de Gladys Marin, secretária geral das JJCC e membro da Comissão Política do PC, os jovens comunistas reconheciam os trabalhadores como vanguarda da luta revolucionária e entendiam que às JJCC cabia de reforçar as ações encampadas por amplos setores populares. Através das JJCC, além das BRP, o PC incentivou diferentes projetos político-culturais com objetivos pedagógicos, como a revista Ramona, centrada em temas relacionados à juventude, e a Discoteca do Cantar Popular (Dicap), um selo criado com o propósito de outorgar espaços de produção e difusão musical para grupos folclóricos ou solistas sem espaço no mercado discográfico da época. Tal selo representou um grande meio de difusão da Nova Canção Chilena, movimento de música de protesto.

Além da valorização da juventude, o XIV Congresso defendeu uma estratégia de conquista do voto feminino. ${ }^{15}$ Julieta Campusano, outro membro da comissão do PC, destacou que deveria ser privilegiada a integração das mulheres trabalhadoras pertencentes às camadas populares. Estas, devido a sua dupla condição de "dona de casa" e trabalhadora, poderiam unir esforços tanto pelas causas de classe como pelas 
questões relacionadas à participação política da mulher na sociedade (ibidem, p.95). Aspectos estes sintetizados na descrição da trajetória de Ramona Parra.

Todo este referencial a que remetia Ramona Parra fundamentaram a criação das brigadas muralistas do PC e se expressaram nas suas mensagens pictóricas. De acordo com o artigo de Ximena Ortuzar, publicado na revista Onda, ${ }^{16}$ a BRP foi organizada, como tal, em 1969. Uma comissão de propaganda do PC definia seus planos de trabalho, que se dividiram em dois momentos: primeiramente, antes da eleição, trabalharam pelo triunfo da UP e, posteriormente, direcionaram suas ações para defender o governo popular (Ortúzar, 1973, p.20-1).

Alejandro González foi o responsável pela divisão dos trabalhos em duas partes: o aspecto político, baseado na discussão e definição de consignas que sintetizassem as idéias e os pontos de vista do partido e que se efetivava nas discussões realizadas antes de sair à rua; e o aspecto artístico, que definiu a maneira de produzir um mural coletivamente, no qual se destacou na hora de colorir (Fontbona et alli, 2002, p.389).

Um informativo da BRP publicado em 1971, e intitulado La revolución chilena no la para nadie! Por esto los reaccionarios conspiran...! (A revolução chilena ninguém pára! Por isso os reacionários conspiram...!), descreve as etapas da organização e as conquistas dessa brigada desde a decisão pela candidatura de Salvador Allende até o primeiro ano do governo da UP. Sobre o período eleitoral, o documento exaltou o caráter voluntário e o apego às convicções ideológicas do programa do governo como elementos que motivaram a ação da juventude comunista e fizeram da BRP um eficiente veículo de propaganda (Brigada Ramona Parra, 1971, p.1). Com isso, a BRP declarava estar a serviço não apenas do PC, mas também do projeto de transição ao socialismo pela via pacífica que tinha Salvador Allende como seu maior defensor.

No último congresso das JJCC, realizado pouco antes das eleições de 1970, as BRP centralizaram sua organização em Santiago e se tornaram órgão oficial de propaganda do partido (Díaz \& Lara, 2004). Passaram a receber uma estrutura nacional que contemplava um comitê central, comitês regionais e locais como o PC. Cada BRP possuía um chefe que fazia parte da comissão política do partido e era responsável por divulgar o tema da mensagem (Fontbona, 2002, et alii, p.405).

Atestando a repercussão dos trabalhos de propaganda eleitoral das BRP, o jornal comunista El Siglo noticiou em 26 de setembro de 1970 a homenagem prestada por parte das direções do PC e das JJCC às BRP e à Brigada Venceremos. Segundo o jornal, para estimular a continuidade dos trabalhos, as JJCC entregaram aos jovens brigadistas 
as diretivas e os planos de trabalho traçados no XXIII Congresso do Partido Comunista da União Soviética (PCUS). Incentivo que estava de acordo com a herança revolucionária do PCUS, no que dizia respeito à educação de seus militantes (El Siglo, 27 set. 1970). ${ }^{17}$

O prestígio no partido contribuiu para que, depois da vitória, sob o lema "Pintaremos até o céu, até vencermos!", as BRP passassem a realizar de maneira mais estruturada e respaldada seu trabalho propagandista e a desenvolver certo experimentalismo artístico. O informativo de 1971 também esclarece a orientação dada aos trabalhos brigadistas depois da vitória, no tópico intitulado $A$ la vanguardia en el trabajo (A vanguarda no trabalho). De acordo com a idéia de vanguarda, as BRP declaravam-se agentes responsáveis pela missão revolucionária de informar os chilenos sobre as lutas a serem enfrentadas pelo governo popular e a respeito das tarefas que cabiam a cada um deles, definindo-os como "jovens incansáveis que se entregaram plenamente à tarefa de educar o povo através de uma arte de massa" (Brigada Ramona Parra, Chile, 1971). Tais pressupostos basearam tanto a ação da BRP nas ruas quanto a simbologia que consolidaram e difundiram através de seus murais.

O cartaz de divulgação da exposição realizada no Museu de Arte Contemporânea da Quinta Normal em Santiago entre 20 de abril e 20 de maio de 1971 reúne os principais símbolos da BRP. Observamos na imagem cores planas e intensas, predominantemente a cor amarela e as cores da bandeira nacional chilena (azul, vermelho e branco), contornadas em preto. Na parte superior está o logotipo das BRP: a mão-bandeira que se desloca, com delicadeza, em direção a uma flor nativa, ambas mão e flor - localizadas sobre o nome das BRP e sua organização de origem, as JJCC. No meio do cartaz estão a mão-pomba-estrela, a foice e o martelo e a mão com a sigla "BRP” que segura o pincel. Por último, na parte inferior do cartaz, constam a mão aberta com a estrela e o rosto de uma mulher com as características dos povos andinos nariz largo, lábios grossos, olhos puxados.

A mão-bandeira se deslocando em direção ao fruto da terra sugere a representação do governo popular (mão envolvida na bandeira) que cuida da nação (flor nativa). Mão-bandeira e flor estão associadas à estrela, que remete à idéia da vitória de um projeto que tinha em suas mãos o poder de resgatar a soberania nacional e valorizar as camadas populares, atendendo às suas necessidades e respeitando suas tradições.

Os três símbolos do centro do cartaz conjugam a proposta revolucionária em questão e as armas de luta utilizadas pelas BRP para defendê-la. A mão esquerda aberta 
que deu forma a uma pomba e levou na sua palma a estrela representa, respectivamente, um projeto de governo revolucionário aberto ao diálogo, democrático, a ser realizado de maneira pacífica (pomba). Em seguida observamos as ferramentas de trabalho - foice e martelo - símbolos dos Partidos Comunistas, que estava disposto a manter a luta pela transição ao socialismo no âmbito institucional de acordo com o executivo. O terceiro símbolo, composto pelo punho fechado (símbolo tradicional das lutas populares) segurando um pincel, estabeleceu a proposta de uma luta popular a ser alcançada por outros meios, que não a violência.

Na parte inferior do cartaz observamos a combinação entre a mão direita aberta desenhada com uma estrela e o rosto sério da mulher com traços andinos. A mão direita aberta estabelece uma contraposição ao punho fechado, símbolo tradicional da esquerda, reforçando uma representação diferenciada das lutas por mudanças como eram encampadas pelos governos socialistas da época. A imagem feminina colocada em posição frontal expressa, como é próprio da frontalidade, uma tentativa de marcar uma atitude de segurança, de audácia, de franqueza (Bellange, 1995, p.43). Isso estava de acordo com o simbolismo mais genérico atribuído à mulher - entendida como expressão da possibilidade de "transcendência", "futuro", "fonte de todo potencial afetivo", "portadora de coragem, de ideal e de bondade" (Feminino, in Chevalier \& Gheerbrant, 1994, p.421) -, ou seja, a representação dos valores exaltados na trajetória de Ramona Parra que a tornaram um exemplo a ser seguido.

Nos painéis da exposição, os símbolos da BRP apareceram mesclados às imagens que incorporavam valores centrais dos pressupostos político-culturais presentes no programa da UP: valorização e resgate da cultura popular, dos trabalhadores como agentes revolucionários e a conscientização política do povo chileno como principais armas de luta para garantir a transição para o socialismo pela via pacífica.

Selecionamos, ainda, quatro murais da BRP que conjugam temáticas recorrentes $\mathrm{e}$, por isso, fundamentais para compreendermos a maneira como essa brigada atuou entre 1970 e 1973.

O mural com a frase "El arte para el pueblo" ("A arte para o povo") foi produzido no dia 5 de setembro de 1970, no dia seguinte à vitória eleitoral de Salvador Allende. A representação composta pela frase e alguns dos símbolos das BRP - o rosto de mulher, a mão esquerda erguida e aberta, e a estrela - expressa a disposição de iniciar uma batalha a partir do rompimento das barreiras culturais existente entre a elite e o povo. A relação entre os símbolos das BRP e o texto coloca o muralismo brigadista 
como caminho para tal aproximação. A mensagem, a preocupação político-cultural de democratizar o conhecimento artístico e a intenção de fazer dos murais de rua mais do que um suporte de informação política do partido para o povo, uma possibilidade de tornar a arte uma forma de manifestação dos anseios populares.

O mural seguinte, segundo Eduardo Carrasco, foi pintado em 1971 na cidade de Temuco, localizada ao Sul de Santiago, região na qual se concentravam os maiores latifúndios do país (Carrasco, 2004, p.56). Ao abordar o tema da reforma agrária, a imagem deu destaque à figura feminina, colocando-a em primeiro plano, com cabelos longos e azulados, braços grandes envolvendo os frutos da terra (uvas, bananas, peras) e sorrindo. As cores estabelecem a identificação entre a mulher e os frutos da terra e, ao mesmo tempo, remetem a uma sensação de luminosidade e calor. Mais à esquerda, em segundo plano, observamos três figuras humanas masculinas vestidas com chapéus e roupas que reproduziram as cores da mulher, dos frutos e, também, a cor da terra. Suas cabeças baixas, como se estivessem protegendo-se do sol, intensificaram a luminosidade e a idéia de esforço no trabalho.

Esse mural é uma alegoria sobre o trabalhador do campo responsável pela produção do alimento que o governo da UP se propunha a fazer chegar à mesa das camadas populares. $\mathrm{O}$ ano de produção da imagem coincidiu com a política de aprofundamento da reforma agrária. Nesta perspectiva, a imagem da mulher carregando os frutos da terra com uma expressão de satisfação remete ao simbolismo que identifica o "seio materno ao seio da terra", ou seja, à fecundidade e à prosperidade da terra gerada pelo trabalho.

A representação do trabalho, ou do processo produtivo na figura 6 , corresponde a um tema recorrente nos murais das BRP difundido para incentivar os trabalhadores na batalha pelo aumento da produção e estabelecer uma contraposição aos boicotes econômicos dos partidos e organizações opositoras da UP. No mural observamos uma narrativa que se expressou através da lateralidade de uma representação composta por três rostos que carregam objetos relacionados ao processo produtivo - no caso, fábricas, ferramentas de trabalho e alimentos - e símbolos que se tornaram marca da própria brigada, como a mão-bandeira e a mulher. $O$ braço e a mão simbolizavam a continuidade da produção e os rostos, em posição lateral, seriam os condutores dos trabalhadores. Já a mulher, olhando frontalmente para o espectador, chama a atenção para a importância desse processo. A maneira lateral, alegórica e colorida deste mural expressa uma característica estilística que marcou as mensagens das BRP depois da 
vitória. A mescla de símbolos da brigada e da esquerda e o recurso à lateralidade que estabelecia a sensação de um deslocamento foram a forma encontrada para descrever um processo em direção ao futuro.

A sensação de deslocamento proporcionada pela lateralidade é retomada no mural seguinte, no qual observamos o contorno de duplas de pessoas com os braços erguidos e levando bandeiras nacionais. Neste caso, o recurso ao deslocamento serviu para representar uma multidão caminhando em uma mesma direção, constituindo a simulação de uma mobilização popular. Esse mural de 1972 com a temática "Adelante!" (“Avante!”) representou a defesa, por parte dos brigadistas das BRP, da mobilização nas ruas como forma de apoiar o governo. Segundo Eduardo Carrasco, "a necessidade de avançar, apesar das dificuldades, fez com que 'ADELANTE!' se tornasse uma palavra de ordem pintada nos inúmeros muros do Chile" (ibidem, p.44). Cabe lembrar que mesmo nos momentos mais difíceis da batalha política encampada pelo governo, Salvador Allende insistiu em convocar os trabalhadores e a juventude para sair em defesa do governo popular através de manifestações nas ruas. ${ }^{18}$ Os muralistas das BRP criaram, então, murais que representavam temáticas como "Avante!" ou, ainda, "Vamos defender o governo popular", convocando os chilenos a apoiar o governo através da mobilização popular.

Nestes murais as BRP apontavam aspectos da maneira como o PC atuou na luta política travada pela UP entre 1970 e 1973. O mural com a frase El arte para el pueblo condiz com as declarações de Alejandro González a respeito das questões que os brigadistas da BRP se colocavam:

Para onde nos dirigimos? Para que cultura? Era necessário saber o que fazer para estabelecer um contato direto com o povo. A classe trabalhadora, as classes médias não têm uma relação natural, própria, com os museus, as galerias, o teatro. Era necessário, então, mudar o lugar, ou melhor, ampliar os lugares indo aonde ia o povo. Mas isso também não era suficiente: não queríamos transportar a cultura para lugares novos, queríamos outra cultura. Trata-se de criar uma maneira para que o povo tome consciência de suas necessidades, que deixe de lado o imperialismo cultural representado pela cultura burguesa e, finalmente, que encontre uma arte que o pertença, que seja a expressão, exteriorizada, da nova realidade. Em um manifesto (Que constituiu depois a medida $40^{19}$ do programa da Unidade Popular), esse Comitê definiu os princípios e os organismos que poderiam ser os fermentos dessa cultura nova, popular e democrática. $\left(\right.$ González, 2003) ${ }^{20}$

Essa missão cultural estava em conformidade com as concepções políticoculturais do programa do governo que, no ponto referente à cultura e à educação, incorporou tais pressupostos na seguinte perspectiva: 
As profundas transformações que se empreenderão requerem um povo consciente e solidário educado para exercer e defender seu poder político, apto científica e tecnicamente para desenvolver a economia de transição ao socialismo, aberto massivamente à criação e que goze das mais variadas manifestações da arte e do intelecto.

Se atualmente os intelectuais e os artistas já lutam contra as deformações culturais próprias da sociedade capitalista, tratam de levar os frutos de sua criação aos trabalhadores e vinculam-se a seu destino histórico, na nova sociedade terão um lugar de vanguarda para continuar com sua ação. Porque a cultura nova não se criará por decreto; ela surgirá da luta pela fraternidade contra o individualismo; pela valorização do trabalho humano contra sua depreciação; pelos valores nacionais contra a colonização cultural; pelo acesso das massas populares à arte, à literatura e aos meios de comunicação contra sua comercialização. (Programa de la Unidad Popular, 1969, p. $40) .^{21}$

O discurso do diretor artístico das BRP por si só, e também se relacionado com o informativo de 1971, demonstra como as brigadas almejavam contribuir com as mudanças para consolidação de uma cultura política socialista através da socialização de uma arte de caráter popular. Nessa acepção de arte e cultura, observamos a ideologia nacional-popular fundamentando a definição do conteúdo e do tipo de manifestação artística e conhecimento intelectual que deveria ser legitimado para se constituir a nova cultura. O nacional, como era defendido no programa da UP, identificava-se com o popular e resgatá-lo significava construir uma memória em uma perspectiva oposta à das camadas dominantes. O povo era a representação do nacional e se dividia entre vanguarda e massa, sendo que esta constituía a parte do povo sem a consciência de seus próprios interesses e que, por essa razão, não se organizava para defendê-los. Já a vanguarda assumia a função de educar e dirigir as massas de acordo com seus interesses. Nestas perspectivas, os Partidos Comunistas fundamentavam sua luta contra o imperialismo desnacionalizante a partir de uma aliança de classes. No cerne deste conceito estaria o resgate da cultura popular que se relacionava, diretamente, com a construção da identidade cultural e da unidade social no país. ${ }^{22}$

As "massas" seriam os agentes da revolução, na medida em que se integrassem nas lutas propostas pelo governo e seus principais partidos - o PC e o PS. No caso da imagem 5, esses agentes seriam então os trabalhadores homens exercendo seu papel na batalha da produção. A representação do trabalhador exercendo sua função colocou em evidência uma tentativa de mudar o significado do trabalho, ou seja, de fazer com que os indivíduos entendessem que sua força de trabalho não seria mais uma mercadoria, mas, uma contribuição fundamental para a construção da sociedade socialista na qual todos seriam os donos dos meios de produção e os bens produzidos seriam de usufruto coletivo. Toda a política cultural da UP estava orientada para esse princípio. 
A imagem 6 intensificou a idéia dos trabalhadores como os agentes a serem integrados na luta, na medida em que os representou como braços e mãos fortes que seguiam a orientação de uma vanguarda (as cabeças que os conduziam). Colocou-se assim a vanguarda (lideranças do PC e das JJCC) como armas de luta e os trabalhadores como a munição, pois estes deveriam executar as tarefas de acordo com a orientação do Partido que se expressava nos murais das BRP.

Uma observação que cabe às três primeiras imagens diz respeito à forma como as representações do masculino e do feminino se diferenciam. Enquanto os trabalhadores (homens) se destacam como protagonistas principais do processo de mudança, a figura feminina, presente na grande maioria das pinturas da BRP, aparece como uma alegoria, ligada às representações da nova sociedade, geradora do homem novo ${ }^{23}$ do futuro relacionado ao socialismo. Representar a figura feminina nas imagens era condizente com a política de inserção das mulheres afirmada no XIV Congresso do PC chileno. Mas sua forma alegórica era paradoxal com a imagem revolucionária constituída a partir da figura de Ramona Parra.

Outro fator importante a ser destacado é o fato de que as pinturas murais das BRP, no conjunto, associaram os símbolos do PC (a foice e o martelo) a imagens referentes à paz, como flores, pombas e mãos abertas. Trazendo, assim, à tona um dos princípios que indicou a via pacífica como uma possibilidade no $\mathrm{XX}$ Congresso do Partido Comunista Soviético, realizado em 1956: a questão da paz internacional. ${ }^{24}$

Desde o Congresso Nacional do Partido Comunista chileno, realizado em abril de 1956 em Cartagena, o PC aprovou um programa que seguia o movimento comunista internacional e valorizava as experiências práticas de coalizões políticas organizadas para disputar o poder no Chile: tinham como metas a libertação nacional, a aliança com setores democráticos e a conquista do apoio da classe trabalhadora. Segundo a historiadora Elisa de Campos Borges, nesse congresso "que foi sustentada a possibilidade de avançar ao socialismo pela via não-armada a partir da conquista do governo pelo movimento popular" (Borges, 2005, p.51-2).

Júlio Faúndez, em sua análise sobre a participação dos partidos de orientação marxista em quarenta anos de regime democrático no Chile, ressalta que o $\mathrm{PC}$, desde o final da década de 1960, seguia a tese baseada na estratégia da frente de libertação nacional formulada no início dos anos 1950 pela URSS como uma resposta à doutrina Truman. Isso subentendia conceber a revolução socialista como um processo a ser realizado em etapas distintas. Na primeira etapa, denominada nacional-democrática, as 
forças populares deveriam aliar-se aos partidos que representassem as forças burguesas progressistas para obterem apoio e realizarem as tarefas democráticas definidas como primordiais: isolar a oligarquia de latifundiários, o imperialismo e o capitalismo monopolistas. Logo que essas tarefas estivessem cumpridas, iniciar-se-ia a etapa de transição ao socialismo (Faúndez, 1992, p.200). Nesta perspectiva, os comunistas assumiam uma postura moderada e baseada na tentativa de assegurar uma relação amena entre a UP e as forças burguesas consideradas progressistas e nacionalistas, o diálogo com o PDC e a colaboração com as Forças Armadas. Postura que implicava, também, a condenação a qualquer tentativa da ultra-esquerda de utilizar meios extraparlamentares de luta.

Tais prerrogativas sintetizam o acordo com o projeto político-cultural defendido por Salvador Allende, no qual o caráter pacífico e democrático da via política optada tornava primordial consolidar no poder do Estado uma nova presença ideológica resultante da consciência de classe revolucionária. Segundo German González Quiroz, Salvador Allende defendia que, para alcançar a coesão ideológica dos trabalhadores, o governo recorresse às possibilidades de penetração dos partidos de esquerda junto às "massas" através da realização de atividades de conscientização política. Enquanto isso, o presidente complementaria essa difusão ideológica cumprindo de forma imediata metas do programa básico (como a Reforma Agrária ou a criação da Área de Propriedade Social (APS)), contribuindo na demonstração de que o governo era dos trabalhadores e, assim, para a unificação ideológica da classe (Quiroz, 1989, p.8). A BRP, então, estruturou-se de acordo com essa lógica na qual o Estado cumpriria metas essenciais para beneficiar os trabalhadores, e organizações como as brigadas muralistas fariam a difusão do que se estava realizando, buscando consolidar uma identificação entre a população e o projeto do governo.

Observemos agora o discurso proferido a partir das BEC.

\section{A Brigada Elmo Catalán}

A Brigada Elmo Catalán (BEC), quando citada na bibliografia sobre o Chile no período de governo da UP, sempre recebeu atenção inferior à BRP, mesmo que, na maioria das vezes, sua abrangência e atuação tenham sido consideradas tão relevantes quanto as da brigada comunista. No entanto, mesmo sendo poucas as informações sobre ela, se pensada em comparação com a BRP, foi possível analisar suas ações 
propagandistas com base na relação entre a organização que a criou - a FJS ${ }^{25}$ - e o seu partido de origem, o PS.

A BEC, segundo Sebastián Fontbona, Nicolas Labra e Ismael Larraín, elaborou as principais representações pictóricas do PS e seus trabalhos, junto com os da BRP, impulsionaram o rápido aumento das manifestações propagandistas ligadas às realizações muralistas (Fontbona et alli, 2002, p.247-8). Ela foi organizada em 1969 e, inicialmente, recebeu o nome de Brigada Central. Quando, em junho de 1970, o jornalista chileno Elmo Catalán, membro do Estado-Maior do Exército de Libertação Nacional (ELN), seção chilena, e do Exército de Libertação Nacional boliviano morreu assassinado em Cochabamba, os militantes da FJS mudaram o nome da brigada para Elmo Catalán com o intuito de homenageá-lo. De acordo com Ximena Ortúzar, a organização da BEC ocorreu, precisamente, em julho de 1970, quando uma delegação da Juventude Socialista (JS) voltou de Cuba depois de ser convidada a participar da colheita da safra de cana-de-açúcar na ilha. Em 1973, essa brigada já contava com mil e oitocentos militantes jovens entre dezesseis e vinte e dois anos. (Ortúzar, 1973). Além de integrantes das JS, participaram da BEC artistas, estudantes e trabalhadores.

As primeiras realizações da BEC datam de uma ação de campanha conjunta organizada pelas diferentes brigadas dos partidos da UP em apoio a Salvador Allende e realizada pouco antes da eleição de 4 de setembro de 1970. Essa iniciativa, chamada de "Al Amanecer venceremos" (“Ao amanhecer venceremos"), ocorreu na noite de $1^{\circ}$ de setembro de 1970, quando centenas de brigadas ao longo do país pintaram nos muros o slogan "Venceremos". ${ }^{26}$ Depois de alcançada a vitória, aos poucos, a BEC buscou, durante o primeiro ano e meio de governo da UP, um aprimoramento estético. Nesse período, seus murais revelaram influências de muralistas mexicanos e chilenos, mas assumiram como marca tipográfica o modelo da letra do cartaz do filme Spartacus de Stanley Kubrick. Esta marca estética revelou sua estreita relação com desenhistas gráficos, especialmente estudantes universitários que introduziram nos murais códigos visuais ligados à publicidade comercial (Calendário Colección Philips,1999, p.24). Relação que também ocorreu entre as BRP e os produtores dos cartazes de propaganda do governo reunidos no Escritório dos Irmãos Larrea. ${ }^{27}$

Estruturadas também em nível nacional e com estilos, cores e temas próprios, a BEC e a BRP foram os dois grandes protagonistas da propaganda política muralista durante o governo da UP: o preto sobre o amarelo da BRP e o vermelho sobre o branco da BEC, cores que as distinguiam. A propósito dos murais da BEC, Sebastián Fontbona, 
Nicolas Labra e Ismael Larraín, baseados em um depoimento de Enrique Romo encarregado nacional desta brigada -, afirmaram que, com a intensificação da ofensiva da oposição ao governo a partir de meados de 1972, a mensagem política direta e sem grandes preocupações artísticas voltou a ser predominante nesta brigada (Fontbona et alli, 2002, p.253-6).

Na FJS, a função das BEC foi, em primeiro lugar, realizar a propaganda política, pois faziam parte das tarefas de educação política legadas pelo PS à juventude socialista. Sebastián Márquez e Carlos Valero, militantes do PS que participaram de trabalhos com as BEC, afirmaram que a iniciativa propagandista e a proposta artística da BRP, por serem pioneiras, serviram de modelo para a organização de brigadas muralistas no PS e, neste partido, representaram uma maneira de iniciar os jovens na militância de forma orientada (Márquez \& Valero, fev. 2004). Assim como a BRP, a BEC realizou experiências coletivas de pintura nas quais também houve uma divisão de trabalho de acordo com a habilidade de cada participante e pautada no objetivo de promoção da arte popular. Um exemplo ilustrativo de iniciativas nesse sentido foi o projeto-piloto realizado em Valparaíso, que visava ensinar para crianças as técnicas da produção de murais em brigadas, para que este tipo de criação tivesse continuidade na futura sociedade socialista (Ávila, set. 2006). A BEC, a sua maneira, compartilhoram a BRP a preocupação com a formação doutrinária dos futuros homens novos da sociedade socialista.

Ao tratar da estrutura organizativa dessa brigada, Ximena Ortúzar ressaltou, citando relatos de um brigadista não identificado, que em cada organização juvenil socialista eram selecionados e preparados os melhores militantes para realizar tarefas de orientação política e cultural através das brigadas. Segundo o relato,

\footnotetext{
O primeiro passo é assistir a uma escola de quadros, onde se aprende organização, traçado, cuidado dos materiais e o mais importante: a conduta durante o trabalho.

- Está proibido falar e fumar durante o desenho. Os que terminam sua tarefa devem subir no caminhão e esperar pelos demais. Sobretudo nos ensinam que "disciplina é segurança".

Ninguém porta armas. Pois é proibido pelo Partido. Por isso, quando ao amanhecer, em qualquer lugar, aparecem os inimigos e os agridem, utilizam duas estratégias de defesa:

- Pular no chão e sair correndo. Claro que eles [os opositores] andam bem prevenidos com paus, pedras e balas. Em Linares, durante a campanha de 1972, tivemos cinco companheiros feridos com metralhadora. Não pudemos fazer muita coisa, porque não somos brigadas de choque, mas propagandistas. (Ortúzar, 1973). ${ }^{28}$
}

$\mathrm{O}$ artigo ressaltou como o papel revolucionário dos brigadistas pautava-se na capacidade de trabalhar de maneira coletiva através da disciplina e de produzir 
mensagens conscientizadoras, colocando a violência como um recurso utilizado de forma desleal pelos adversários políticos da UP. Também Eduardo Castillo Espinoza ressaltou a maneira pacífica como a BRP e a BEC realizavam seus trabalhos destacando ainda, a relação amistosa entre elas. No entanto, as representações difundidas pela BEC, na maior parte dos murais analisados, não expressam essa negação do confronto violento.

Em seus murais a BEC não difundiu mensagens com o recurso a símbolos diversificados e inovadores, ela reproduziu uma simbologia tradicional da esquerda que, a partir da representação da imagem de certos ícones, buscou consolidar uma identidade revolucionária contrária ao projeto da UP. Sua representação mais recorrente foi a imagem do guerrilheiro, sobretudo de Che Guevara, e símbolos relacionados a ele, como observamos nos fragmentos dos murais apresentados em uma exposição realizada em 1971.

A BEC elaborou essa imagem para um evento realizado pela Federação de Estudantes da Universidade do Chile (FECH), em outubro de 1971, em homenagem ao dia do Guerrilheiro Heróico ("Che Guevara”). Mesmo ano da visita de Fidel Castro ao Chile, que durou mais de trinta dias. O mural composto por uma representação de Che Guevara junto à bandeira cubana foi documentado fotograficamente porque registrava a presença do presidente socialista Salvador Allende no evento. Tal referência pode parecer previsível devido à temática da exposição, porém, além de não termos encontrado informações a respeito da participação das BRP nesse evento, os murais das BEC produzidos nas ruas com o objetivo de fazer propaganda política mantiveram uma apologia constante a esse modelo revolucionário.

$\mathrm{Na}$ representação pictórica do tabuleiro de xadrez, encontramos uma clara referência à idéia de confronto. Este é estruturado na forma de um jogo onde ocorre um embate entre uma única peça escura e valiosa do jogo de xadrez e outras claras menos valiosas (os peões), porém em maior número. Mesmo nesta relação assimétrica, o choque entre as duas forças gerou um desequilíbrio geral. A utilização do jogo de xadrez como forma de expressar o confronto é de grande significado, na medida em que representa uma estratégia guerreira, de combate entre forças opostas e a tentativa de domínio e destruição do adversário. ${ }^{29}$ Nesse combate observamos uma representação maniqueísta do choque de forças adversárias: o bem (peões claros) contra o mal (peça escura e valiosa). 
O tabuleiro de xadrez representava o Chile, os peões eram os agentes revolucionários, ou seja, os trabalhadores que, unidos e organizados, jogavam contra a peça mais valiosa, no caso, o capitalismo, o imperialismo estadunidense e as camadas dominantes chilenas. Os trabalhadores com suas bandeiras aparecem se deslocando em direção ao inimigo e a partida não está definida. A imagem representou, assim, a situação limite, de profunda tensão, que caracterizou as disputas políticas no Chile durante o governo da UP. Porém, enquanto este mural apresenta um diagnóstico da luta eminente, definindo as forças opositoras e sua disposição para o confronto violento observemos que a pomba (símbolo da paz) localizada no fundo da representação está levantando vôo -, as imagens seguintes apontaram as armas a serem utilizadas para que os trabalhadores saíssem vitoriosos.

No mural intitulado Trabajadores al poder (Trabalhadores ao Poder), observa-se uma alegoria que remete ao conflito em questão, porém neste caso aparece representada uma dualidade nos artifícios de luta a serem utilizados pelos trabalhadores. Ao reunir a imagem de um operário à de uma mão que empunha uma ferramenta de trabalho, com o mesmo destaque proporcionado à representação da arma de fogo e da bandeira do Chile, a pintura coloca o recurso da luta armada como uma possibilidade a ser considerada no processo revolucionário chileno. Mas não o único, pois a arma do trabalho (ferramenta) está colocada em igualdade de condição. Esta idéia se reforça quando constatamos que, entre todos esses símbolos, no lado direito, há uma figura, em primeiro plano, de um homem de barba (como os guerrilheiros da Sierra Maestra que tomaram o poder em $\mathrm{Cuba})^{30} \mathrm{e}$, um pouco mais ao fundo, uma mulher que tem à sua frente e na altura do seu colo a imagem de um jovem vestido com a bandeira chilena. Em seguida, na outra face do mural, a mensagem se completa com a imagem de um grande punho fechado representação metonímica das reivindicações populares - sobre o título, Trabajadores al poder. As duas mulheres apresentadas na primeira face do mural aparecem relacionadas à maternidade.

A imagem atesta que as BEC também valorizaram os trabalhadores como agentes centrais das transformações e o trabalho como meio de luta, porém, deixa claro que esta não deveria ser a única. Nesse sentido, através da recorrente imagem do guerrilheiro, defendem a mudança da estratégia revolucionária a ser seguida para efetivar a transição ao socialismo. Já a imagem da mulher foi incorporada à representação ainda como uma alegoria que remete ao futuro que se seguiria à luta dos trabalhadores e resultaria na formação do homem novo. 
No conjunto das imagens da BEC analisadas houve coerência entre o nome escolhido para a brigada - Elmo Catalán -, que homenageava um guerrilheiro chileno que morreu lutando na Bolívia, e as mensagens dos murais. A presença de Elmo Catalán na guerrilha boliviana fez parte da política internacionalista do PS, vigente nos anos 1960, quando o partido mandava seus agentes participarem de diferentes lutas internacionais. Nesse período, conforme atestou Carlos Altamirano (secretário-geral do PS), o PS apoiou o movimento guerrilheiro boliviano, uruguaio (Tupamaros) e argentino (Montoneros) (Altamirano, 1979, p.16).

Segundo a linha de seu partido, também a FJS, desde 1957, manteve estreitas relações com diferentes organizações revolucionárias, especialmente com as cubanas que lutavam contra o ditador Fulgencio Batista, e tomou Che Guevara como modelo de revolucionário a ser valorizado (Valle \& Díaz, 1987, p.43-4). Tanto a FJS quanto as JJCC estabeleciam suas ações políticas baseadas nas pautas em discussão de seus partidos e realizavam debates entre si sobre as decisões tomadas. ${ }^{31}$ Porém, em momentos de reavaliação de estratégias do partido, as linhas políticas assumidas pela FJS, muitas vezes, divergiam do Comitê Central (CC) do PS, interferindo nos debates e nas decisões da comissão política.

Divergências neste sentido foram apontadas por Jorge Valle e José Díaz, principalmente depois da campanha e da derrota da Frap em 1964. A partir de então a FJS passou a fazer duras críticas à condução da campanha, à linha eleitoral do PS e do PC e a defender de maneira mais enérgica a integridade do socialismo revolucionário, o que significava uma maior valorização das categorias de base do partido e a aplicação da política da Frente de Trabalhadores.

Frente de trabalhadores era o nome da tese sobre a natureza da revolução no Chile apoiada pelo PS na época da formação da UP. A partir dela, os socialistas defendiam três pontos: uma aliança apenas entre partidos políticos que representassem os interesses do proletariado e das camadas populares em geral, o rechaço a uma aliança com organizações políticas da burguesia e a revolução como um processo único, no qual as tarefas democráticas e socialistas deveriam ser realizadas simultaneamente. (Faúndez, 1992, p.200-2). Para o PS, o programa da UP deveria ser uma reafirmação desta estratégia, de forma que o futuro governo, em uma única etapa, precisaria combinar as tarefas democráticas e nacionais contra a oligarquia local e o imperialismo $\mathrm{e}$, ainda, realizar projetos socialistas. Tese que se contrapunha à estratégia da frente de libertação nacional seguida pelo PC. 
O posicionamento do PS pautava-se no diagnóstico definido no XXII Congresso do partido realizado em Chillán no ano de 1967 em que, ao discutirem o desenvolvimento da frente de trabalhadores, optaram pela luta armada como via de acesso ao poder (Valle \& Díaz, 1992, p.51). Conforme Carlos Altamirano, a definição pela via armada não pressupunha o uso da violência em todas ou algumas fases do processo; ao contrário, considerava a utilização, enquanto fosse possível e eficaz, da institucionalidade burguesa e das formas legais de luta. No entanto, uma vanguarda revolucionária dos trabalhadores deveria estar preparada para encampar a via insurrecional, se necessário, nos instantes decisivos do processo (Altamirano, 1979, p.54). Cabe-nos observar que essa explicação é bastante vaga e não muda o fato de o PS considerar a luta armada.

Ao defender a linha da frente de trabalhadores, a FJS gerou conflitos na Frap Juvenil com as JJCC, tendo em vista que estas, fiéis à linha eleitoral do PC, seguiam uma política de atuação em todas as frentes de massas de acordo com a frente de libertação nacional. Dessa forma, até o início da campanha da UP, em 1969, as juventudes dos principais partidos de esquerda do Chile formaram chapas próprias nas eleições universitárias, sendo que a FJS passou a estabelecer listas junto com o Movimiento de Izquierda Revolucionário (MIR). ${ }^{32}$

Quando em março de 1970 o PS avaliou as possibilidades eleitorais abertas para os partidos de esquerda e aceitou compor uma coligação mais ampla, que incluísse o PR (considerado representante da pequena burguesia) e a via pacífica como estratégia política de transição ao socialismo, o candidato Salvador Allende e o subsecretário-geral do partido, Adonis Sepúlveda, participaram do Congresso Nacional da FJS. O objetivo dessa participação era esclarecer o papel da juventude socialista na campanha e no governo da UP, conforme havia sido definido na Conferência do Programa de 1969. A FJS assumiu a organização de uma campanha de recrutamento, batizada de "Contingente 'Che Guevara'", que visava esclarecer outros jovens e as camadas populares em geral, sobre o sentido revolucionário que distinguia a UP e da importância da sua participação nas tarefas delegadas pelo futuro governo (Valle \& Díaz, 1992, p.54).

A direção da FJS, sobretudo a partir da vitória eleitoral da UP, interrompeu as discussões sobre as condições revolucionárias e sobre as vias doutrinárias para a transição ao socialismo no Chile, passando, como o PS, a defender o fortalecimento da UP. No XXIII Congresso Geral do PS, realizado na cidade de La Serena em janeiro de 
1971, no qual Carlos Altamirano foi eleito secretário-geral, o partido adotou uma linha política de respaldo aos Comitês de Unidade Popular (CUP) para garantir a mobilização e a incorporação da população nas tarefas que dependiam da participação popular como, por exemplo, na batalha da produção. Coube à FJS realizar ações voltadas à conscientização da população, então com o objetivo de obter apoio para a UP nas disputas eleitorais em plano nacional (eleições parlamentares e municipais), no âmbito sindical (as eleições da CUT), e no campo juvenil (nas federações universitárias e secundárias). Nesse congresso a participação direta da FJS na direção do partido aumentou consideravelmente e a ação direta nos CUP demonstra a intenção do PS de se tornar a vanguarda revolucionária da etapa de transição para o socialismo.

Na prática, a nova orientação não impediu, desde o período eleitoral até o último ano de governo da UP, ações que feriam a linha doutrinária do governo por parte de integrantes do os, como, por exemplo, o apoio a treinamentos de guerrilha ${ }^{33}$ e ações armadas nas ruas da capital Santiago. ${ }^{34}$ Posturas que geraram fortes descompassos entre a FJS e o CC do PS, bem como pontuaram as diferenças nas relações das juventudes socialista e comunista com seus partidos de origem e com o projeto da UP.

As imagens das BEC associadas à conduta da base militante do PS, especialmente à da FJS, que, na sua maioria, defendia estratégias revolucionárias caracteristicamente ultra-esquerdistas e, muitas vezes, obtinha apoio de importantes dirigentes do partido, expressaram ambigüidades presentes na conduta do PS desde a sua formação.

As principais linhas ideológicas que constituíam o PS, quando da formação da UP em 1969, dividiam-se entre os leninistas; os castristas; e os moderados ou socialdemocratas. A grande diferença entre esses segmentos estava em suas táticas. Nessa época os castristas tinham forte penetração na juventude e seu porta-voz era Carlos Altamirano. Eles predicavam a insurreição armada e esperavam que os sindicatos desorganizassem o sistema existente, formando, junto com os trabalhadores rurais, as tropas que levassem a cabo a revolução. Os moderados, fração mais numerosa do partido, tinham Salvador Allende como dirigente extra-oficial e defendiam o caminho econômico, a estratégia eleitoral e a formação de alianças com partidos não-socialistas como o Partido Radical (PR). Foi esse grupo que liderou a campanha eleitoral de 1964 e conseguiu, especialmente devido à representatividade política de Salvador Allende, ampliar a coligação de esquerda e formar a UP em 1969. 
No decorrer do governo da UP o PS, ao mesmo tempo em que escolheu Salvador Allende para ser o candidato da UP, em 1971 elegeu Carlos Altamirano para secretáriogeral, este que era defensor da formação da frente de trabalhadores. Com isso fica clara a dificuldade do PS para associar as diversas tendências políticas de seus integrantes em uma direção comum, permitindo que seus líderes e militantes, como os integrantes da BEC, realizassem ações ou propagassem nas ruas do Chile mensagens que feriam princípios centrais do programa da UP.

\section{Murais Brigadistas e o Imaginário da Experiência Chilena}

Estudar a história da experiência chilena a partir das imagens de propaganda produzidas com o apoio dos partidos de esquerda e do governo nos permitiu resgatar aspectos da mobilização política e cultural do período que revelaram não somente as condições da sua produção, mas os objetivos dos produtores de imaginários de efeitos pedagógicos. A maneira como cada brigada tentou cumprir sua função de conscientização e orientação política resultou, por um lado, em representações orientadas por valores comuns aos partidários das transformações socialistas: a adesão à luta dos trabalhadores, expressa nas roupas utilizadas pelos brigadistas e no trabalho coletivo representado na sua organização em brigadas e nas imagens dos murais. No entanto, por outro lado, ao descrever o meio de luta para efetivar tais mudanças, criaram representações divergentes sobre um mesmo processo e, portanto, uma "luta de representações" reveladora da relação dialética entre imaginários e práticas sociais, que geraram sentidos paradoxais à propaganda política da UP.

As brigadas muralistas, então, ao mesmo tempo em que foram eficazes na integração e participação das organizações juvenis dos principais partidos do governo e realizaram murais que legou a elas o lugar de segunda tendência muralista na história da arte chilena, também acentuaram no espaço público a dificuldade do governo de manter uma unidade de ação. Nas suas imagens observamos a permanência da dualidade de estratégias do PC e do PS que marcaram suas condutas até o último ano de governo, impediram a unidade da coalizão e dificultaram as tomadas de decisão. 


\section{REFERÊNCIAS BIBLIOGRÁFICAS:}

ALtAMIRANO, Carlos. Dialética de uma derrota. Chile 1970-1973. São Paulo: Brasiliense, 1979.

ANGELL, Allan. Partidos políticos y movimiento obrero en Chile. México: Ediciones Era, 1974.

ARCHIVO SALVADOR ALLENDE. Las tareas de la juventud. Estudio-TrabajoCompromiso. Mexico: Universidad Pedagogica Nacional, 1990.

ÁVILA, Ximena. A. Entrevista concedida à autora deste trabalho, et. 2006.

BELLANGE, Ebe. El Mural como reflejo de la realidad social en Chile. Santiago: Ediciones Chile America Cesoc, 1995.

BORGES, Elisa. C. O projeto da via chilena ao socialismo do Partido Comunista chileno: Nem revisionismo, nem evolucionismo, nem reformismo, nem cópias mecânicas. São Paulo, 2005. 238 f. Dissertação (Mestrado em História) - Setor de Ciências Humanas, Pontifícia Universidade Católica, p.54-6.

BRIGADA RAMONA PARRA (Chile). La revolución no la para nadie: por esto los reaccionarios conspiran...! Santiago, s/n, 1971.

CALENDÁRIO COLECCIÓN PHILIPS. El Mural em Chile. Santiago: Philips Chilena S.A, 1999.

CANCLINI, Nestor Garcia. A socialização da arte: teoria e prática na América Latina. São Paulo: Cultrix, 1980.

CARRASCO, Eduardo. Il sogno dipinto. I murales del Cile nella memoria storica. Itália: Hobby \& Work Publishing, 2004.

CHEVALIER, Jean. e GHEERBRANT, Alain. Dicionário de símbolos. Mitos, sonhos, costumes, gestos, formas, figuras, cores, números. Trad. Vera da Costa e Silva, Raul de Sá Barbosa, Ângela Melim e Lúcia Melim. 8. ed. Rio de Janeiro: José Olympio, 1994.

CLEARY, Patrício. Cómo nació la pintura mural política Chile. Revista Araucaria de Chile, n.42, p.93, 1988.

DALMÁS, Carine. Brigadas Muralistas e Cartazes de Propaganda da Experiência Chilena. São Paulo, 2006. 191 f. Dissertação (Mestrado em História) - Faculdade de Filosofia, Letras e Ciências Humanas, Universidade de São Paulo.

DÍAZ, Paloma A. T. e LARA, M. L. El arte muralista de las Brigada Ramona Parra 1967 - 1973. Santiago, 2004. 40 f. Monografía - Departamento de Ciencias Históricas., 
Universidad de Chile. Disponível em: <http://www.colectivobrp.cl>. Acesso em: 15 jun. 2005.

DRAGO, Tito. Chile: Um duplo seqüestro. São Paulo: Thaurus, 1995.

FAÚNDEZ, Júlio. Izquierdas y democracia en Chile. Trad. José Cayuela. Santiago de Chile: Ediciones BAT S.A., 1992.

FERNANDES, Florestan. Da guerrilha ao socialismo: a Revolução Cubana. São Paulo: T. A. Queiroz, 1979.

FISCHER, Kathleen. Political Ideology and Educational Reform in Chile. Los Angeles: UCLA, 1979.

FONTBONA, Sebastián; LABRA, Nicolás; LARRAÍN, Ismael. La ciudad como papel. Santiago de Chile, 2002. 524. f. Tesis para optar al grado de Licenciatura en Comunicación Social. - Escuela de Publicidad. Universidad Diego Portales.

GONZÁLEZ, Alejandro. El arte brigadista, $<$ http://www.abacq.net/imagineria/arte4.htm> Acessado em: 30 set. 2003 . Entrevista concedida a autora deste trabalho. Santiago de Chile: 19 fev. 2004.

JARA, Joan. Canção inacabada. A vida e a obra de Victor Jara. Trad. Renzo Bassanetti. Rio de Janeiro/São Paulo: Editora Record, 1998

LANZAROTTI, Cláudia. Habla la hermana de Ramona Parra. Revista Ramona, Santiago, n.18, 29 fev. 1972.

LEON, Carlos. El muralismo chileno: comunicación y arte. Revista Araucaria de Chile. França, n. 24, 1983.

MÁRQUEZ, Sebastián, VALERO, Carlos. Entrevista concedida à autora deste trabalho. Santiago de Chile, 18 fev. 2004.

MENESES, Ulpiano Bezerra. Fontes visuais, cultura visual, história visual. Balanço provisório, propostas cautelares. Revista Brasileira de História, São Paulo, v.23, n. 45, p. 11-36, jul. 2003.

ORTÚZAR, Ximena. "Mística a todo color", Revista Onda, Santiago, n. 45, 26 maio 1973.

PARTIDO COMUNISTA DE CHILE. Intervenciones y resoluciones del XIV Congreso. (Celebrado entre el 23 y el 29 de noviembre de 1969). Santiago, 1970.

PAZ, Octavio. Pintura Mural. In: México en la obra de Octavio Paz III - Los privilegios de la vista. Arte de México. México: Fondo de Cultura Económica, 1987.

PROGRAMA DE LA UNIDAD POPULAR. Santiago, 1969. 
QUIROZ, Germán González. Arte y cultura en la via chilena al socialismo: El discurso cultural y la producción artística en el gobierno de Unidad Popular. Santiago de Chile, 1989. 75 f. Monografía - Departamento de Estética.

REVISTA RAMONA. Santiago, n. 55, p. 18-29, 13 nov. 1972.

RIDENTI, Marcelo. Em busca do povo brasileiro: artistas da revolução do CPC à era da TV. Rio de Janeiro: Record, 2000.

SCHNAIDERMAN, Boris. Os escombros e o mito. A cultura e o fim da União Soviética. São Paulo: Companhia das Letras, 1997.

VALLE, Jorge e DÍAZ, José. Federación de la Juventud Socialista. Apuntes Historicos. 1935-1973. Chile: Ediciones Documentas, 1987.

DALMÁS, Carine. The muralistic brigades from chilean experience: political propaganda and revolutionary imaginary. História, São Paulo, v. 26, n. 6, p. 226-256, 2007.

Abstract: The aim of the present article is to analyze two propaganda organizations and some of the murals which were produced by them in Chile during the government of the Popular Unit. At that time, the Chilean left attempted to develop the project of transition into socialism by peaceful means. The images were created with propagandistic ends by muralistic brigades, which belonged to the main government parties - the Communist Party and the Socialist Party. The ways in which they were structured and the pictorial and textual messages that were produced by these organizations allowed us to observe some aspects of the role the main government parties had in the political and cultural struggle they waged in favor of this common project. Our analysis is based on the assumption that the images created translate, as historical documents, the political and ideological values of the Popular Unit, as well as its internal political tensions. The aim of the muralistic brigades was to awaken society's political awareness and gain its support in order to transform Chile into a socialist country, which ultimately contributed to the construction of a socialist imaginary. The study of the ways in which Popular Unit's visual propaganda disseminated that imaginary constitutes the central axis of the present work, which circumscribes itself, from a historiographical standpoint, in the field of the history of representation. It is our understanding that the analysis of the images expressed in the murals allows us to apprehend the meaning of the imaginary which directed the political practices of the Communist and Socialist Parties in Chile at that time.

Keywords: Muralistic Brigades, Chilean Experience, Social Imaginaries.

Artigo recebido em 09/2007. Aprovado em 12/2007. 


\title{
NOTAS:
}

\begin{abstract}
${ }^{*}$ Mestre em História Social pela Universidade de São Paulo. Autora da dissertação de mestrado intitulada Brigadas Muralistas e Cartazes de Propaganda da Experiência Chilena (1970-1973), com apoio financeiro da CAPES. E-mail: cadalmas@yahoo.com.br.

${ }^{1}$ A UP foi criada em 1969 através de uma aliança de três grandes partidos: Partido Comunista (PC), Partido Socialista (PS) e Partido Radical (PR); e três pequenas organizações: o Partido Social Democrata (PSD), o partido de Ação Popular Independente (API) e o Movimento de Ação Popular Unificado
\end{abstract} (Mapu).

${ }^{2}$ É importante ressaltar que se pretende trabalhar na perspectiva de Ulpiano Meneses, que, ao propor métodos de utilização de fontes visuais na pesquisa histórica, ressalta que o seu papel não corresponde ao de objeto de pesquisa, mas de instrumento para o entendimento de uma certa problemática a respeito de uma sociedade. Ver: Meneses, 2003, p.11-36.

${ }^{3}$ Em 1957 a lei eleitoral tornou o voto obrigatório, gerando um crescimento substantivo na participação popular e feminina, e estabeleceu a cédula única de votação para dificultar as fraudes eleitorais (Faúndez, 1992, p.129-30).

${ }^{4}$ A FRAP foi uma aliança eleitoral entre comunistas e socialistas iniciada em 1956, que marcou o rompimento dos 20 anos (1936 a 1956) de coalizão entre partidos de esquerda e partidos representantes de uma "pequena burguesia reformista", no caso o Partido Radical (PR). Este, até então, sempre foi majoritário e indicava um candidato seu para encabeçar as alianças. A partir de 1956, até a formação da UP, a FRAP só incorporou partidos de esquerda e lançou candidatos que representavam os trabalhadores.

${ }^{5} \mathrm{O}$ pacto eleitoral do PC e do PS em torno da FRAP em 1958 obteve um grande êxito eleitoral: enquanto o primeiro colocado, Jorge Alessandri, do Partido Nacional (PN), obteve $31 \%$ dos votos, a FRAP, representada por Salvador Allende, obteve 29\%, sendo que o restante dividiu-se entre o PDC (21\%) e o PR (15\%).

${ }^{6}$ A revista Araucaria de Chile, produzida trimestralmente por exilados chilenos ligados ao PC de 1978 a 1990, tinha o objetivo de unir a produção cultural dos chilenos que viviam no Chile e os que estavam no exílio, constituindo uma alternativa de manifestação político-cultural em meio à censura e à repressão impostas pela Junta Militar que assumiu o governo em setembro de 1973. Um estudo sobre as idéias políticas e culturais, que circularam nesta revista durante o período de sua publicação, está sendo realizado pela historiadora Êça Pereira da Silva, no projeto intitulado Araucaria de Chile 1978-1990: a intelectualidade chilena exilada, no Programa de Pós-Graduação em História Social da Universidade de São Paulo.

${ }^{7}$ Eduardo Frei Montalva desfrutava de uma grande quantidade de recursos, do apoio de profissionais qualificados (jornalistas, sociólogos, psicólogos, especialistas em comunicação social) e de uma agência publicitária que introduziu novas perspectivas à propaganda política no país. Recursos provenientes de investimentos da direita, concentrada em torno do Partido Nacional (PN), e do governo dos Estados Unidos, ambos preocupados em impedir a eleição da Frap. O interesse dos Estados Unidos estava de acordo com a sua política da Aliança para o Progresso, aplicada pelo presidente Kennedy na América Latina para conter a propagação do comunismo na América Latina. (Faúndez, 1992, p.132-3).

${ }^{8}$ Neste ponto Patrício Cleary ressalta a escassez de recursos para adquirir materiais para a realização dos murais. Situação que, segundo Eduardo Carrasco (militante comunista que participou do movimento da Nova Canção Chilena e das BRP), foi resolvida com materiais doados por operários do porto de Valparaíso: Sacos de fumo preto, cola de carpinteiro e uma quantidade considerável de baldes de metal. Com este material, foram preparados cerca de dois mil litros de "pintura preta" (Carrasco, 2004, p.19).

${ }^{9}$ Este massacre aconteceu no mês de março de 1970, na província de Llanquihue por ordem do Ministro do Interior do governo, Edmundo Pérez Zúcovic, responsável pelo grupo móvel e toda a máquina repressiva da polícia entre 1964 e 1970. A ação se deu contra um grupo de 91 famílias de agricultores sem terra que tinham ocupado terras em Pampa Irigon, situado cerca de três quilômetros do centro da cidade de Puerto Montt. Os policiais utilizaram bombas de gás lacrimogêneo, atiraram contra as famílias e incendiaram as choças. Mataram sete lavradores e uma criança de 9 meses morreu asfixiada pelo gás (Jara, 1998, p.72).

${ }^{10}$ Alejandro "Mono" Gonzalez, importante participante e formulador do projeto político e cultural das BRP, era pintor muralista e militante do PC. Segundo um artigo da revista Ramona (revista do PC publicada entre 1970-1973), Alejandro González pintava desde os onze anos de idade, foi aluno da Escola Experimental Artística de Santiago entre 1960-1967, das Escolas de Belas-Artes da UChile e da Universidade Católica. Porém, teria sido no curso de desenho teatral na UChile que encontrou a possibilidade de colocar sua arte a serviço da comunidade. Participou na campanha presidencial de 1964, 
pintando murais com os jovens da Frap (Los “monos" de la BRP en las salas de arte, Revista Ramona, 1972, p.18-9). Como atestaram também artigos do jornal comunista El Siglo e do jornal Correo de Valdivia, desde seus primeiros trabalhados muralistas participou de projetos que tinham como propósito estabelecer o contato do povo chileno com a arte (El Siglo, 29 jun. 1964; El Correo de Valdívia, 10 fev. 1968).

${ }^{11} \mathrm{O}$ movimento muralista mexicano originou-se na década de 1920 e é considerado a expressão artística da Revolução Mexicana, iniciada em 1910. Seus idealizadores defendiam uma arte pública, coletiva, reveladora da identidade nacional do povo. Os trabalhos analisados que apresentam diferentes perspectivas de análise e, assim, proporcionam uma compreensão global da importância deste movimento, são Octavio Paz (1987), Dawn Ades (1997), Toby Clark (2000) e Camilo Vasconcellos (2003).

${ }^{12} \mathrm{Na}$ efemeridade dessa produção muralista encontramos a maior dificuldade da pesquisa: recuperar dados como localização e autoria de muitos dos murais analisados. As imagens obtidas são fragmentos existentes através de registros fotográficos da época compilados e expostos na website Breve Imagineria Política, criada pelo fotógrafo chileno Fernando Orellana na França. Fernando Orellana reuniu imagens fotográficas de murais das brigadas e cartazes guardados por militantes da UP que viviam no exílio nos mais diversos países. Outros murais são reconstituições publicadas recentemente pelo músico chileno Eduardo Carrasco (2004), que também participou das Brigadas Ramona Parra entre 1970 e 1973, e alguns foram obtidos na website desta brigada, chamada Colectivo BRP. Por esse motivo, muitos dos registros trabalhados apresentam-se em preto e branco.

${ }^{13}$ Houve uma influência do muralismo mexicano entre os pintores chilenos que remonta à década de 1940 com a chegada dos pintores Xavier Guerrero e David Alfaros Siqueiros. Este último deu palestras na Escola de Belas-Artes da Universidade do Chile e em outras instituições, introduzindo novas técnicas de pintura mural e influenciando uma geração de pintores muralistas chilenos que produziram obras dispersas, mas não constituíram uma tradição. As brigadas muralistas foram consideradas outra tendência do muralismo chileno em comparação com o trabalho destes artistas. Sobre a formulação desta diferenciação e a influência dos muralistas mexicanos ver: Departamento Educativo del Museo Nacional de Bellas Artes (1984), Ebe Bellange (1995) e Patrício Rodríguez-Plaza (2004).

${ }^{14}$ A revista Ramona era editada semanalmente de 28 de outubro de 1971 a 11 de setembro de 1973 . Foi uma publicação da JJCC, portanto voltava-se para a juventude. Suas temáticas percorreram os acontecimentos políticos, culturais e comportamentais que marcaram o Chile e o mundo no início da década de 1970 .

${ }^{15}$ Tal resolução estava de acordo com a constatação de que as mulheres, na sua maioria, apoiavam o PDC. O próprio documento do XIV Congresso ressaltou que na eleição de $1964,56,7 \%$ dos votos das mulheres chilenas foram para a DC e apenas $13,5 \%$ para a Frap.

${ }^{16}$ A revista Onda, definida como uma revista de política e cultura da UP, produzida pela divisão de publicações infantis e educativas da Empresa Editora Nacional Quimantú Ltda.; com a participação da Direção Nacional de Centros Juvenis, Conselho de Desenvolvimento Social, Odeplan e o Departamento de Educação da Universidade do Chile (UChile). Seus temas variavam entre os principais acontecimentos políticos e realizações culturais (cinema, música, literatura, artes plásticas, sexualidade) do governo e das organizações de esquerda. Seus textos geralmente destacavam as ações da juventude, as disputas políticas dentro das suas organizações, exaltavam as conquistas do governo e criticavam o sectarismo dos partidos de esquerda e as práticas sediciosas da direita. Era um periódico claramente favorável ao presidente Salvador Allende, na medida em que os diversos artigos lidos se encerravam com lições que defendiam a unidade em torno do processo de transformação política que se operava no país. O editor da revista era Patrício Garcia, e seu diretor, Wilson Tapia. Os números consultados encontram-se anexados junto à lista de fontes utilizadas para a pesquisa.

${ }^{17}$ Próximo ao modelo de partido fraternal e centralizado da URSS o PC despertou um alto grau de entrega entre muitos de seus militantes e conquistou uma reconhecida força interna e coesão. Em 1970, o PC possuía uma base formada por trabalhadores e era um partido forte dentro do movimento operário chileno (base esta que faltou a outros partidos comunistas da América Latina e com o apoio de alguns sindicatos se tornou o principal agente da classe operária nas zonas de nitrato do Norte do país e nas minas de carvão do Sul. Vale ressaltar também que entre os partidos que compuseram a UP, o PC era o partido que dispunha de maior apoio eleitoral - 15\% do eleitorado chileno votava regularmente no PC nos anos 1970 - Angell, 1974, p.96-7).

${ }^{18}$ Em outubro de 1972 ocorreu uma paralisação provocada pelos donos das transportadoras que parou o país e marcou o encerramento da possibilidade de diálogo entre a UP e o PDC. Na seqüência dos acontecimentos as forças armadas assumiram cargos no governo para garantir as eleições parlamentares de março de 1973 gerando uma crise política entre os partidos do governo que se intensificou com a 
tentativa de golpe armado por facções militares em junho, mas que foram derrotadas pelo governo. No entanto, em meio a todo este quadro e poucos dias antes do golpe militar de 11 de setembro de 1973, Salvador Allende ainda convocou uma mobilização geral de trabalhadores e estudantes para demonstrar a força do governo e comemorar os três anos da vitória eleitoral.

${ }^{19}$ A medida quarenta do programa da Unidade Popular referia-se à criação do Instituto Nacional de Arte e de Cultura (INAC) e de escolas de formação artísticas em todas as comunidades. Porém, este instituto não chegou a ser efetivado.

${ }^{20}$ Trecho traduzido pela autora.

${ }^{21}$ Trecho traduzido pela autora.

${ }^{22}$ De acordo com a categoria de nacional-popular a cultura, durante o governo da UP, também foi tomada como instrumento político na tradição da esquerda nacionalista da época, que se fundamentava nas concepções dos Partidos Comunistas, defendidas ao longo dos anos 1950 e 1960 a respeito do que seria o nacional e o popular. A origem dessas definições que inspiraram vários programas de cultura latinoamericanos nas décadas de 1960 e 1970 pautou-se nas formulações de Antonio Gramsci, que deu um lugar de destaque para a cultura nas lutas sociais e políticas, considerando a luta cultural um momento essencial na transformação socialista da sociedade. Os textos consultados para a abordagem do conceito de nacional-popular nesta perspectiva foram Antonio Gramsci (1978), Marilena Chauí (1983), Antonio Albino Canelas Rubim (1987) e Marcelo Ridenti (2000).

${ }^{23}$ A formação de um homem novo seria o resultado esperado da realização da política cultural da UP e significava o povo consciente de seu papel revolucionário na construção e manutenção da sociedade socialista. Sobre como a idéia de homem novo foi formulada na experiência chilena, ver Fischer, 1979, p.74-5. De maneira mais geral, a preocupação com a formação de um homem novo era condizente com a utopia revolucionária da década de 1960 que valorizava a vontade de transformação e a ação dos seres humanos para mudar a História. Conceituação nascida com Marx e recuperada por Che Guevara para quem o homem novo não era apenas o objetivo final da revolução, mas aquele que garantiria a persistência das transformações da sociedade na direção certa. Neste sentido, para entendermos a etimologia do conceito, os textos consultados foram: Fernandes (1979) e Ridenti (2000).

${ }^{24}$ Esta via política foi constituída, principalmente, a partir das teses do XX Congresso da União Soviética, realizado em 1956, após a morte de Stalin em 1953. Nesse congresso foram denunciados os crimes políticos de Stalin, através de um relatório apresentado por Krushov (primeiro secretário do Comitê Central do Partido Comunista da União Soviética - PCUS), e iniciou-se um debate acerca da via pacífica ao socialismo. Esse congresso desenvolveu o princípio da coexistência pacífica entre países de sistemas sociais opostos, no caso, entre capitalistas e comunistas, tendo em vista o contexto de Guerra Fria. O que estava em questão era a tentativa de estabelecer melhores relações entre URSS e EUA, e se sustentava que a luta violenta não era inevitável para a transição ao socialismo. Constatada a amplitude e a organização da luta das camadas populares contra o perigo da guerra, a classe operária era vista como uma das principais forças motrizes para evitar a guerra, mas desde que atuasse como força organizada e unida. Deve-se ter em vista que se tratava de um momento em que o mundo acabava de sair de uma guerra mundial e clamava-se pela paz internacional. A tese da via pacífica, conforme defendeu a URSS neste congresso, dividiu o mundo comunista entre o PCUS e o Partido Comunista Chinês. Este criticava o projeto da via pacífica porque acreditava que isso desanimaria muitos movimentos revolucionários de tentarem a tomada do poder em alguns países, pois tudo acabaria em um acordo feito entre os dois países dos blocos capitalista e socialista. A historiadora Elisa de Campos Borges, na dissertação de mestrado em que abordou o projeto da via chilena ao socialismo do Partido Comunista Chileno, apresenta uma síntese dos principais autores que abordam a questão da via pacífica ao socialismo (Borges, 2005, p.54-6).

${ }^{25}$ A Federação da Juventude Socialista (FJS) era a coordenação nacional de todas as Juventudes Socialistas (JS) estruturadas nas diversas regiões do Chile e a responsável pela organização dos congressos nacionais, nos quais se definiam as linhas a serem seguidas pelas categorias juvenis do PS. (Valle \& Díaz, 1987).

${ }^{26}$ Dessa iniciativa temos documentado fotograficamente apenas uma mural realizado pela BRP. Ver: Carine Dalmás (2006)

${ }^{27}$ À análise desta relação dediquei um subcapítulo da minha dissertação de mestrado. Ver: Carine Dalmás (idem).

${ }^{28}$ Trecho traduzido pela autora.

${ }^{29}$ É preciso considerar, no importante simbolismo do jogo de xadrez, de um lado, o jogo propriamente dito, e de outro, o tabuleiro sobre o qual ele se desenrola. O simbolismo deste jogo, originário da Índia, liga-se claramente ao da estratégia guerreira ... O Desenrolar do jogo é um combate entre peças negras e peças brancas, entre a sombra e a luz, entre os titãs (asura) e os Deuses (deva). ... Porque o tabuleiro é uma representação do mundo manifestado, tecido de sombra e de luz, em que se alternam e equilibram o 
yin e o yang. (...). O tabuleiro é, portanto, o campo de ação das potências cósmicas (Burckhardt), campo que é o da terra (quadrada), limitada nos seus quatro orientes. ... O Tabuleiro de xadrez simboliza a tomada de controle, não só sobre o adversário e sobre um território, mas também sobre si mesmo, sobre o próprio eu, porquanto a divisão interior. (Chevalier \& Gheerbrant, 1994, p.966-7).

30 A forma como os revolucionários cubanos tornaram a barba também um símbolo da revolução é ressaltada por Jean Paul Sartre no seu livro "Furacão sobre Cuba".

${ }^{31}$ É importante ter-se em conta que os debates entre as FJS e a JJCC baseavam-se nas pautas de discussão dos seus partidos de origem. Por exemplo, em 1962 ao mesmo tempo em que o PC e o PS discutiam as linhas da política internacional e as vias de construção do socialismo na Frap, aconteceram paralelamente a XVII Conferência Nacional da FJS e uma plenária da JJCC. Nesses eventos as organizações juvenis debateram separadamente e em conjunto a mesma pauta dos partidos com o objetivo de organizar a Frap Juvenil, buscando métodos objetivos de ação e a unidade entre as juventudes (Valle \& Díaz, 1987, p.44).

32 O MIR era uma organização de tendência ultra-esquerdista, que pautava sua conduta em táticas extraparlamentares e estava profundamente identificado com a Revolução Cubana.

${ }^{33}$ Jorge Valle e José Díaz destacaram o caso Chaihuin, ocorrido em maio de 1970, como exemplo deste descompasso de posturas. Em Chahuin foram presos, pelas forças de segurança do governo democrata cristão, seis jovens que integravam um centro de treinamento de guerrilheiros, entre os quais quatro eram vinculados ao PS. Esta descoberta, segundo os autores, foi profundamente explorada pela imprensa de direita e pela governamental para colocar em xeque o caráter pacífico da revolução proposta pela candidatura de Salvador Allende e gerou dúvidas entre os demais partidos da UP, a respeito do tipo de apoio que o PS estaria disposto a dar à candidatura à Presidência da República. Diante deste acontecimento, o secretário-geral do PS no período, Aniceto Rodríguez, negou publicamente que os detidos fossem militantes socialistas, e os líderes das JS da região Sul do país (Ñuble e Concepción) declararam, publicamente, solidariedade aos companheiros presos (ibidem, p.54-5).

34 O jornalista chileno Tito Drago, em diferentes momentos, ressaltou como certas pretensões vanguardistas do PS deram ensejo para a realização de ações isoladas que geraram conflitos internos no PS e resultaram em duras críticas por parte dos demais partidos da coalizão governista, sobretudo o PC, e indignação do presidente Salvador Allende. Neste sentido, o autor relatou uma ação de rua organizada no mês de maio de 1973, que envolveu os principais líderes do PS (secretário de organização do PS, Ariel Ulloa, e o secretário-geral Carlos Altamirano) e comitês do Partido, em Santiago. O objetivo da ação era, através da intensificação das manifestações dos militantes socialistas, disputar e dominar as ruas que estavam sendo tomadas pelo movimento Pátria e Liberdade e o pelo Comando Rolando Matus do PN. As estratégias de confronto, delegadas por Ariel Ulloa aos militantes do comitê socialista da região Sul, do Centro e da Cordilheira, incluíam o uso da violência física e armas de fogo. No dia da ação foram utilizadas armas de fogo, o que resultou no assassinato do chefe do grupo de ação do movimento Pátria e Liberdade, Mario Aguilar, e no ferimento de outros integrantes dos grupos de oposição. Os militantes do PS saíram vitoriosos, poucos tiveram ferimentos leves e conseguiram desmobilizar os grupos opositores. Cumpriram a missão de recuperar o protagonismo das ruas, conforme havia solicitado o CC, porém, diante da repercussão política de tal fato, o CC negou que a participação de militantes socialistas neste confronto e atribuiu o acontecimento aos grupos de extrema direita. A negação da autoria do conflito ocasionou indignação das bases do PS, sob a justificativa de que haviam cumprido vitoriosamente uma orientação do CC e, sendo assim, sua ação deveria ter sido valorizada. Por outro lado, o presidente Salvador Allende recriminou o paralelismo do CC, exigiu a entrega e a destruição das armas utilizadas pelos militantes de seu partido e decretou estado de emergência em Santiago (Drago, 1995, p.119-25). 